IZA DP No. 10196

Remittances and Informal Work

Artjoms Ivlevs

September 2016

Forschungsinstitut zur Zukunft der Arbeit Institute for the Study of Labor 


\title{
Remittances and Informal Work
}

\author{
Artjoms Ivlevs \\ Bristol Business School (UWE Bristol) \\ and IZA
}

\section{Discussion Paper No. 10196 \\ September 2016}

\author{
IZA \\ P.O. Box 7240 \\ 53072 Bonn \\ Germany \\ Phone: +49-228-3894-0 \\ Fax: +49-228-3894-180 \\ E-mail: iza@iza.org
}

Any opinions expressed here are those of the author(s) and not those of IZA. Research published in this series may include views on policy, but the institute itself takes no institutional policy positions. The IZA research network is committed to the IZA Guiding Principles of Research Integrity.

The Institute for the Study of Labor (IZA) in Bonn is a local and virtual international research center and a place of communication between science, politics and business. IZA is an independent nonprofit organization supported by Deutsche Post Foundation. The center is associated with the University of Bonn and offers a stimulating research environment through its international network, workshops and conferences, data service, project support, research visits and doctoral program. IZA engages in (i) original and internationally competitive research in all fields of labor economics, (ii) development of policy concepts, and (iii) dissemination of research results and concepts to the interested public.

IZA Discussion Papers often represent preliminary work and are circulated to encourage discussion. Citation of such a paper should account for its provisional character. A revised version may be available directly from the author. 
IZA Discussion Paper No. 10196

September 2016

\section{ABSTRACT}

\section{Remittances and Informal Work ${ }^{*}$}

This paper studies the effects of remittances on informal employment in the migrants' countries of origin, looking both at the remittance-receiving and non-migrant households. Using data from the Social Exclusion Survey, conducted in six transition economies in 2009, I find that receiving remittances increases the likelihood of working informally. At the regional level, high prevalence of remittances is associated with a higher likelihood of informal work among non-migrant households. Migration and remittances may thus be contributing to informal employment in migration-sending countries.

JEL Classification: F24, J46, J61, R23, O17

Keywords: remittances, migration, informal work, non-migrant households, transition economies, two stage residual inclusion

Corresponding author:

Artjoms Ivlevs

Department of Accounting, Economics and Finance

Bristol Business School

University of the West of England

Bristol BS16 1QY

United Kingdom

E-mail: a.ivlevs@uwe.ac.uk

\footnotetext{
* I thank Ira N. Gang, Ksenia Gatskova, Don Webber, Michail Veliziotis and the participants of the conference "Labour in East and Southeast Europe: Institutions and Practices between Formality and Informality" (Regensburg), the Biannual EACES Conference (Budapest) and the SOLE/EALE World Meetings (Montreal) for many useful comments and suggestions.
} 


\section{Introduction}

International migration and informal employment are salient features of the labour markets across the world. It is estimated that $3.2 \%$ of the world population live outside their country of birth (United Nations, 2013) and a further 13\% of the world's adults would like to emigrate (Clifton, 2013). Migrant remittances have been growing steadily over the last twenty years, showing resilience to the global economic crisis and reaching US\$ 435 billion in 2014 (World Bank, 2014). At the same time, 60\% of the global workforce do not have formal job contracts (OECD, 2009). Both informal employment and remittances are important, and controversial, policy variables: despite their ability to alleviate poverty and sustain livelihoods for millions of households, informality reduces tax revenues and undermines the rule of law, while migration deprives countries of the valuable human capital.

A large literature has shown that remittances can have a significant impact on the labour supply of the remittance-recipient household members (see, e.g., Acosta (2007), Airola (2008), Jadotte (2009), Kim (2007), Justino and Shemyakina (2012)). However, little is known about the links between remittances and informal employment of remittance recipients. While moving abroad and working informally can be viewed as mutually exclusive strategies to deal with poverty at the individual level, complex feedback mechanisms are likely to exist between the two at the household and community levels. For example, remittances may induce remittance receivers to switch from more lucrative but insecure informal work to less well-paid but more secure formal work. Remittances can also provide the recipients with capital for starting a small business or working as self-employed; as self-employment tends to be informal, remittances would encourage informality - both at the household and a wider community level. Given the extent and policy relevance of both remittances and informal sector, it is important to understand whether remittances encourage or discourage informal work among remittance receivers.

This paper explores whether remittances are an important determinant of informal employment among (a) remittance-recipients and (b) non-recipients living in areas with high incidence of remittances. Geographically, the analysis focuses on the post-socialist economies of Eastern Europe and Central Asia. This region is particularly well suited to study the links between the two phenomena. Probably nowhere else in the world have the 
informal sector and migration grown so rapidly in a relatively short period of time. The disintegration of manufacturing industries, trade ties and monetary unions, which followed the collapse of the Socialist bloc, provided a fertile ground for the rise of informality; fifteen years after fall of communism the informal sector in transition economies was estimated to be one third of the gross domestic product - on a par with emerging and developing economies (Buehn and Schneider, 2012). Migration and remittances also grew rapidly as the postsocialist countries opened their borders to the outside world. Currently the countries of the region have some of the world's highest emigration rates and their economies rely significantly on migrant remittances. ${ }^{1}$

The analysis is based on data from the Social Exclusion Survey, conducted in Kazakhstan, FYR Macedonia, Moldova, Serbia, Tajikistan and Ukraine in 2009. I estimate the relationship between remittances and three labour market outcomes: not working, working formally and working informally. Both correlational and instrumental-variable analyses suggest that receiving remittances increase the likelihood of informal work. I also find that people from non-migrant households are less likely to work formally and more likely to work informally if the share of households receiving remittances in a particular region is high.

This study makes a number of contributions to the existing literature on the effects of remittances on employment outcomes. First, it explicitly considers the effects of remittances on formal and informal work. The literature, reviewed in section two, has so far mostly studied the effects of remittances on employment in general, but has not distinguished between formal and informal work (an important exception is Abdulloev, Gang and LandonLane (2012), who study the link between remittances and informal activities in Tajikistan). Second, the study explores possible effects of remittances on the employment outcomes of people who do not receive remittances. The country-level literature (Posso, 2012) has suggested community-level effects of remittances on employment of non-migrant households. I test whether such links exist at the individual level, paying particular attention to informal employment. Third, this paper provides microeconomic evidence on how remittances affect labour market outcomes in a multi-country setting. Many micro-studies

\footnotetext{
${ }^{1}$ For example, emigrants make up $22-45 \%$ of population in Albania, Armenia, Bosnia and Herzegovina, Georgia, FYR Macedonia and Moldova, and remittances are equivalent to $17-52 \%$ of gross domestic product in Armenia, Kosovo, Kyrgyzstan, Moldova and Tajikistan (World Bank data on emigration rates for 2010 and remittances for 2012).
} 
have so far presented one-country evidence, which may limit the generalizability of their findings. Finally, this paper advances our understanding of what drives informal employment in transition economies and beyond. Besides the classical segmented-labour-market argument that informality is driven by the lack of (or difficult access to) formal jobs (Lewis, 1954), more recent literature has also emphasised the role of labour market regulation, labour income taxation, and social benefit design in driving informality (see, e.g., Lehmann and Myravyev, 2014; Koettl and Weber, 2012). ${ }^{2}$ This paper suggests that migration and remittances might be contributing to or sustaining informal employment in migration-sending countries.

The paper proceeds as follows. Section two reviews the literature and outlines testable hypotheses. Sections three presents data and variables. Section four discusses the estimation strategy. Section fives presents and discusses the results, followed by conclusions in section six.

2. Remittances, unemployment and informal work: insights from the literature, theoretical channels and hypotheses to be tested

A well-established literature has proposed a number of theoretical channels through which remittances can affect the remittance receivers' participation in the labour market. First, a standard Neoclassical argument suggests that remittances raise people's reservation wages and discourage their participation in the labour market (Drinkwater et al., 2009; Justino and Shemyakina, 2012). Second, assuming there is a lag between emigration and time when remittances start flowing in, the departure of a migrant may force the remaining family members to work more to compensate for the lost labour and income (Binzel and Assaad, 2011; Gagnon and Khoudour-Castéras, 2011). Migrant family members may also choose to work more to defray the incurred migration costs (Justino and Shemyakina, 2012; Posso, 2012). Third, remittances can help people pay for child and elderly care and enable carers, especially women, to participate in the in labour market. However, it can also be argued that higher reservation wages resulting from remittances encourage people to switch from waged

\footnotetext{
${ }^{2}$ Williams (2015) provides an excellent overview of the competing theoretical perspectives on the origins of informality.
} 
to household work (Gagnon and Khoudour-Castéras, 2011). Fourth, remittances can provide the necessary capital to start a small business or work as self-employed, thus increasing employment in the migrant household and beyond (Posso, 2012); sending a migrant abroad can indeed be viewed as a household strategy for raising capital in the presence of imperfect credit markets (Stark, 1991). Finally, remittances can encourage the neighbouring nonmigrant households to work more in order to help household members migrate after they become aware of the benefits of remittances (Posso, 2012).

These conflicting theoretical channels find reflection in mixed empirical findings. A number of household-level studies have shown that the members of remittance-recipient households are less likely to work or work less hours than people in similar circumstances but not receiving remittances (Acosta, 2007; Airola, 2008; Jadotte, 2009; Kim, 2007; Justino and Shemyakina, 2012). Some gender differences have also been found: for example, in Mexico, remittances are associated with a lower labour supply of women but not men (AmuedoDorantes and Pozo, 2006; Hanson, 2007). A more mixed picture is obtained at a country level. Drinkwater et al. (2009) find an insignificant relationship between unemployment and remittances for a panel of 20 countries (where remittances are equivalent to at least $1 \%$ of GDP). Jackman (2014) obtain an inverted V-shaped relationship between remittances and unemployment in Latin American and Caribbean countries: remittances and unemployment are correlated positively (negatively) if the remittances-to-GDP ratio is lower (higher) than $3.25 \%$. Posso (2012) finds that remittances have a positive effect on the labour force participation rate in a panel of sixty-six developing countries. This result is supported by the household-level study of Piracha et al. (2013), who find that, in Tajikistan, receiving remittances lead to increased opportunities of working in own business.

Despite the large body of literature on the effects remittances on employment in general, the question of whether remittances affect informal work has received very little attention. Abdulloev et al. (2012) represent an important exception. They explore the link between participation in informal activities, captured by the gap between reported income (including remittances) and reported expenditures, and receiving remittances in Tajikistan. They obtain a negative correlation between the two phenomena - the gap between expenditures and income is lower for remittance-receiving households - and conclude that remittances and informal activities are substitutes. Drawing on the observation that most migrants from Tajikistan are low-skilled, Abdulloev et al. (2012) argue that the low skilled people have 
limited opportunities to participate in the lucrative segments of the local informal sector, and choose to emigrate instead. The high-skilled, on the contrary, find it more attractive to participate in the domestic informal activities. This explanation lets the skill level to determine, prior to migration, whether a person (or members of the same household) will migrate or participate in the lucrative segment of the informal market. As such, it does not allow some members to migrate and for others to work informally and does not consider post-migration feedback effects of remittances on informal employment of those left behind.

Yet, remittances can affect informal employment in a number of ways. First, remittance receivers may wish to switch from more lucrative informal jobs to less well-paid formal work, but gain in terms of job security and social guarantees. Alternatively, if remittances are considered a more efficient and generous safety net relative to the social guarantees of formal employment, remittance receivers may choose a more lucrative ${ }^{3}$ but less secure informal work.

Second, remittances may provide people with capital for starting a small business or working as self-employed. As jobs in small businesses and self-employment tend to be informal, remittances will be associated with informality. It is important to note that causality here can run both ways: on the one hand, remittances can make stayers consider starting a new business or becoming self-employment; on the other, household-level decision to start a new business or become self-employed can drive migration and remittances. The new businesses channel would also suggest that in localities with a high share of remittance receivers there will be many small-scale businesses which will employ more people from the non-migrant households. Remittances can thus encourage informal employment beyond the remittancereceiving household.

Another community-level channel can be formulated along the insights provided by Posso (2012). He conjectured that the neighbours of remittance-receiving households may become aware of the benefits of remittances and decide to send a member of their household abroad. To cover migration costs, these non-migrant households may start working more. Posso (2012) used this conjecture to explain why, in developing countries, higher remittances lead

\footnotetext{
${ }^{3}$ At least some of the informal wage premium is transition economies is driven by "envelope" wages - a part of the salary that employers do not declare to reduce taxation. See also Staneva and Arabsheibani (2014), who find that, in Tajikistan, net earnings in the informal sector are higher than in the formal sector.
} 
to higher labour market participation. It could be added that, in order to keep up with the consumption levels of the remittance-receiving households, people from non-migrant households may be willing to earn extra cash by increasing their labour marker participation at home, i.e., they do not necessarily need to send a migrant abroad. Extending this line of reasoning, it can be argued that the 'neighbours' effect is particularly likely to encourage informal employment. If the objective is to raise a finite sum of money rather than assure a continuous income stream, informal work may be a more appropriate option than a longercommitment formal work.

Drawing on the theoretical perspectives discussed above, I test two hypotheses:

1) Receiving remittances increases the likelihood of informal employment among the members of remittance-receiving household.

2) In a particular locality, a higher share of remittance-receiving households increases the likelihood of informal work among people who do not receive remittances.

\section{Data and variables}

Data

The data for this study come from a survey administered by the UNDP/UNICEF in six postSocialist economies - Kazakhstan, Macedonia, Moldova, Serbia, Tajikistan and Ukraine - in November-December 2009. The survey was implemented as part of the preparation of a Regional Human Development Report on Social Inclusion for Eastern Europe and Central Asia (UNDP, 2011). National samples consist of approximately 2,700 face-to-face interviews per country (2,400 in Serbia); there are 15,901 observations altogether. An identical questionnaire, translated into local languages and comprising 136 questions, was used in all surveyed countries. Multi-stage random sampling was employed to create national samples. The primary sampling units were drawn using census, administrative and electoral information; subsequently, households were selected via the random route method, and respondents within households were selected with the nearest birthday method. The national samples are representative of the countries' age, gender and territorial distributions. Further 
information about survey design, methodology and implementation can be obtained from United Nations Development Programme (2011).

\section{Variables}

\section{$\underline{\text { Dependent variable }}$}

To estimate the effects of remittances on informal work, I distinguish between three labour market outcomes -1) not working, 2) having a job with a formal contract and 3) working informally - and analyse them in a unified framework. Concentrating only on respondents who work (formally and informally) may lead to a selection bias, as the unemployed are unlikely to be randomly selected from the population.

To generate a three-state variable, I use two (nested) questions. First, the respondents were asked, "During the last month, have you worked for payment (in cash or in kind) or for any other income at least for one day?" If the answer to this question was affirmative, the respondents were asked, "What is your formal status at your current job?" A menu of the following answers was offered: 1) working on an unlimited permanent contract, 2) on a fixed term contract of less than 12 months, 3 ) on a fixed term contract of 12 months or more, 4) on a temporary employment agency contract, 5) on apprenticeship or other training scheme, and

6) without a written contract (informal). I use the negative answer to the first question to capture not working, then merge answers (1)-(5) to the second question to form a category formal work, and use answer (6) to capture informal work.

\section{Main regressor}

The variable capturing the fact of receiving remittances draws on a question, "Have you or someone else in your household received any of the following types of income over the past 12 months?", with one of the possible answers being "Help from relatives or friends abroad". $12.5 \%$ of all respondents reported receiving remittances. There is, however, a large variation across countries: the share of remittance-receivers ranges from 2-3\% in Kazakhstan and Ukraine to 5-8\% in Serbia and Macedonia to 26-30\% in Moldova and Tajikistan. 


\section{Control variables}

The set of socio-demographic controls includes dichotomous variables for gender, having children, six age groups, four education levels (primary, secondary, secondary vocational, tertiary), being an ethnic minority, being a student, retired, assisting on a family business, four types of settlement (village, small town, economic/regional centre, and capital), as well as variables capturing household income ${ }^{4}$ and self-reported health. To account for all country-level effects, which might affect both the labour market outcomes and the flow of remittances, I include dummy variables for the six countries.

\section{Estimation strategy}

The model to be estimated can be expressed as follows:

$$
\begin{aligned}
\text { Labour Market Status }_{i j}= & \alpha_{1}{ }^{*} \text { remittances }_{i j}+ \\
& \alpha_{2}{ }^{*} \text { socio-demographic controls } s_{i j}+ \\
& \alpha_{3}{ }^{*} \text { country fixed effects } j+ \\
& \text { unobserved error term } \text { tej }_{i j}
\end{aligned}
$$

where the dependent variable captures the labour market status (not working, working formally and working informally) of individual $i$ living in country $j$, and $\alpha_{1}$ through $\alpha_{3}$ are the parameters (parameter vectors) to be estimated. Given the categorical and unordered nature of the dependent variable, I estimate the model with multinomial probit. ${ }^{5}$

\footnotetext{
${ }^{4}$ The respondents were asked into which of six specified income bands their personal monthly income fell, and what was the percentage contribution of their personal income to their total household income. The personal income measure was constructed using the income bands' mid-points (the point for the highest income band was linearly projected from the mid-points of the two previous bands). Information on the respondent's income contribution to the total household income was then used to calculate household income, and the OECD equivalence scale (first adult $=1$, other adults $=0.5$, children $=0.3$ ) was used to calculate equivalised household income. Finally, for comparability, the equivalised household income was expressed in USD, using the Purchasing Power Parity exchange rates for 2009 (source: World Bank, 2012).

${ }^{5}$ As a robustness check, the model was also estimated with the Heckman selection procedure, where, in the first stage, individuals choose whether to work or not and, in the second stage, whether to work formally or informally. Using subjective health as an identifying variable, the Heckman correction model produced the same results as multinomial probit (results are available on request). Given that the Heckman selection model does not deal with endogeneity and cannot easily accommodate instrumental variables, I decided to use the multinomial probit as the main method of estimation.
} 
The estimation of the effect of remittances on different types of employment is challenging due to the potential endogeneity of remittances. Reverse causality is one source of endogeneity. People may decide to leave the labour force (e.g. go into education or retire early) or work informally (e.g. become self-employed) prior to any emigration decision; sending migrants abroad and receiving remittances may be one way to achieve such goals. If such reverse causality exists, the evidence based on the correlational analysis would not be appropriate for policy advice: for example, a negative association between receiving remittances and informal employment would not necessarily mean that remittances cause informal employment. One way to establish the effect of remittances on different types of employment is to use instruments - factors which are highly correlated with the likelihood of receiving remittances but are independent from, or external to, the employment decision of the remittances receiver.

A particular challenge relates to the running of instrumental variable estimation where the dependent variable is not continuous. Terza et al. (2008) show that in a non-linear model (such as multinomial probit used in this paper) the standard two stage least squares estimation will not produce consistent results; instead, they recommend using a two-stage-residualinclusion (2RSI) estimation which will produce consistent results. The idea of the 2SRI estimation is to run a standard first stage regression, where a potentially endogenous regressor (receiving remittances) is explained by the instruments and control variables, and to include the predicted $1^{\text {st }}$ stage residuals, alongside the endogenous regressor, into the second stage equation. ${ }^{6}$ The estimated coefficient of the endogenous regressor in the second stage represents the unbiased effect of remittances on the three-state labour market outcome, while the coefficient of the predicted residuals captures the endogeneity bias. Formally, the 2SRI procedure can be expressed as follows:

$$
\begin{array}{ll}
\text { First stage: } & \operatorname{REMIT}_{i}=\beta_{1} * I N S T R_{i}+\beta_{2} * X_{i}+u_{i} \\
\text { Second stage: } & L M S_{i}=\gamma_{1} * R E M I T_{i}+\gamma_{2} * u_{i}{ }^{e s t}+\gamma_{3} * X_{i}+\varepsilon_{i}
\end{array}
$$

where, for each individual $i, R E M I T$ is a variable capturing the fact of receiving remittances, INSTR is a set of instrumental variables, LMS is a three-state variable capturing labour

\footnotetext{
${ }^{6}$ See also Ivlevs and King (2012) for a detailed explanation of the 2SRI estimation technique, as well as its application to the analysis of the emigration decision.
} 
market status, $\mathrm{X}$ is a vector of socio-demographic characteristics and country-fixed effects, $u$ is the error term of the first-stage regression, $u^{\text {est }}$ is the predicted residual from the first-stage equation, and $\varepsilon$ is the error term in the second-stage regression.

An advantage of the 2RSI estimation is that the coefficient of the predicted residuals $\gamma_{2}$ represents a direct test for the exogeneity of the regressor of interest (Bollen et al. 1995). If it is not statistically different from 0 , one accepts the null hypothesis that the regressor is exogenous and the model should be estimated by a non-linear regression (in our case, multinomial probit).

\section{Instruments}

To be valid, instruments must be highly correlated with the endogenous regressor (instrument relevance) and should not have a direct influence, apart from the influence through the endogenous regressor, on the dependent variable (instrument exogeneity). The first instrument candidate is based on the question, "Some 25 years ago, did your household meet its needs for food by growing vegetables or fruits or keeping poultry or livestock?", with possible answers "No, not at all", "Yes, for up to one-tenth of the household's food needs", "Yes, for between one-tenth and a half of household's food need" and "Yes, for half or more of the household's needs". Growing vegetables/ fruits or keeping poultry in 1985 (before the collapse of socialism) would indicate that households faced hardships in meeting their food needs using income from employment. It also could indicate that such households were successful in diversifying their sources of income (or, more precisely, sources of food).

Arguably, the relative poverty in 1985 positively affected the likelihood of emigration and receiving remittances after the fall of socialism. The ability and experience of diversification of income/ food sources could also be important for migration. Sending some family members abroad and receiving remittances is often viewed as a strategy to hedge against risks facing households and smooth consumption in case of shocks (Stark and Bloom, 1985, Stark, 2009). If household strategies of income diversification persist over time, those households which used to diversify food supply (through subsistence agriculture) before the fall of socialism would also be more likely to diversify the sources of income (through migration) 25 years later. 
Overall, $33 \%$ of respondents said their households were not involved in subsistence agriculture; this share ranges from $27 \%$ in Moldova to $47 \%$ in Macedonia. I create a dummy variable subsistence agriculture equal to 1 if, in the mid-1980s, a household was involved in subsistence agriculture (regardless of the percentage of household food needs that it was meeting) and 0 otherwise. I expect this variable to correlate positively with the likelihood of receiving remittances.

The second instrument candidate relates to the level of ethnic diversity in the settlement where the respondent lives. There exists a large literature linking diversity and socioeconomic outcomes; one part of this literature suggests that ethnic and linguistic diversity, especially at the country level, is associated with inferior outcomes - lower GDP growth, lower literacy rate, lower investment, lower provision of public goods, less political freedom, higher infant mortality, higher extent of corruption and higher incidence of civil conflicts (Alesina et al., 2003; Alesina and La Ferrara, 2005; Montalvo and Reynal-Querol, 2005; Miguel and Gugerty, 2005), while other contributions show that the role of ethnic fractionalisation positive (Gisselquist et al., 2016) or insignificant (Fearon and Laitin, 2003). Through its effect of socio-economic outcomes, ethnic diversity could also be a driver of emigration and remittances - both for the ethnic majority and minority; there would be more (less) migration if ethnic diversity leads to inferior (superior) socio-economic outcomes. In addition, there is also theoretical and empirical literature suggesting that, for various reasons, the ethnic minorities have higher willingness to migrate compared to the ethnic majority (Ivlevs, 2013; Pichler, 2009; Docquier and Rapoport, 2003; Hughes, 2005). One could, therefore, expect that, at the local level, people finding themselves in a minority position (even if they belong to the majority at country level) would be more likely to migrate - and send remittances back home.

To capture the settlement-level ethnic diversity, as well as the respondent's minority status within a settlement, I use information that the interviewers (and not the interviewees) had to provide about the share of the respondent's ethnic group in the settlement, by choosing one of the following bands: "less than 10\%", "10-20\%", "20-40\%", “40-60\%", "60-80\%" and "more than $80 \% "{ }^{7}$ Using this information, I create two dummy variables: 1) ethnically mixed

\footnotetext{
${ }^{7}$ One can be very critical about how precise the interviewer's estimates about the share of the respondent's ethnic group in the settlement are. It is not clear what such information would be based on (observation, prior knowledge) and whether there would exist official statistics (at the settlement level) for the interviewers to refer
} 
settlements, which equals one if the share of the respondent's ethnic group is $40-60 \%$, and 2) a within-settlement minority, which equals 1 if any of the first three bands was chosen (i.e., the respondent belongs to an ethnic group which makes up less than $40 \%$ of the settlement population). It is a priori unclear whether ethnically mixed settlements is associated with the likelihood of receiving remittances positively or negatively, while within-settlement minority is expected to be associated with the endogenous regressor positively.

I will check whether the instruments are relevant by testing for joint significance of the instruments in the first stage regression. F-statistic higher than the commonly accepted threshold of 10 would indicate that the instruments are sufficiently good predictors of remittances. In addition, I expect the three instruments to be individually statistically significant in the first stage regression. Instrument exogeneity in a 2SRI estimation can be tested by including all but one instrument in the second stage equation (which contains the predicted residuals, the endogenous regressor and controls). The joint insignificance of the included instruments indicates that they are exogenous (Bollen et al., 1995). ${ }^{8}$

\section{RESULTS}

\subsection{Remittances and the labour market status of remittances receivers}

Table 1 shows the results of a multinomial probit estimation which does not account for the endogeneity of remittances. To facilitate result interpretation, I report the (average) marginal effects. The results suggest that, controlling for other factors, people from remittancereceiving households are 4.3 percentage more likely to be not working, 5.9 percentage points less likely to be employed formally and 1.6 percentage points more likely to be employed informally. The magnitude of these estimates is non-negligible relative to the average incidence of the three labour market outcomes (54.8, 37 and $8.2 \%$, respectively); the results

\footnotetext{
to and/or to verify the information they provide. However, one could argue that interviewers would provide less biased and more precise information about ethnic shares than the interviewees (who would probably want to overestimate the share of their ethnic group). Overall, I believe that, despite being subjective and potentially imprecise, the information on the share of respondent's ethnic group in the settlement is unique and insightful, and I make use of it in the analysis.

${ }^{8}$ Similarly to the overidentification test in 2SLS model, instrument exogeneity here is tested on the assumption is made that one of the instruments is exogenous. There is no direct test of the exogeneity of all instruments.
} 
thus suggest that remittance receipt is associated with a $19.5 \%$ increase in the likelihood of informal employment relative to the sample average.

Concerning other variables, men, younger people, people with lower levels of education, those assisting in family business, linguistic minorities and village-dwellers are more likely to say they are employed informally. Formal work is more prevalent among men, people in the middle of the age distribution, better educated and people with higher incomes. Finally, women, both younger and older people, people with lower levels of education and income, students, the retired, those assisting on a family business, the least healthy and people from rural areas are more likely to say that they do not work.

Table 2 reports the marginal effect of the variable of interest (receiving remittances) when the model is estimated for each of the six countries. Similar to the whole-sample result, there is a tendency for the marginal effect to be positive on the informal work and out of labour force outcomes and negative on the formal work outcome. However, the magnitude and statistical significance of the results differs across countries. Receiving remittances has a statistically significant association with working informally only in Tajikistan, where members of remittances-receiving households are 2.7 percentage points more likely to work informally. Remittances are associated with a lower likelihood of formal work in Moldova, Tajikistan and Ukraine (the marginal effects range from 3.7 to 10.4 percentage points) and a higher likelihood of not working in Moldova and Ukraine (the marginal effects are 7 and 9.8 percentage points). Noteworthy, the whole-sample results are, to a large extent, driven by countries which depend most on remittances (Tajikistan and Moldova). 
Table 1. Receiving remittances and labour market outcomes: multinomial probit marginal effects

\begin{tabular}{|c|c|c|c|}
\hline & Not working & Formal work & Informal work \\
\hline Receives remittances & $0.043^{* * *}$ & $-0.059 * * *$ & $0.016 * *$ \\
\hline Female & $0.077 * * *$ & $-0.026 * * *$ & $-0.052 * * *$ \\
\hline Has child(ren) & -0.011 & 0.002 & 0.008 \\
\hline \multicolumn{4}{|l|}{ Age } \\
\hline $18-24$ & $0.130 * * *$ & $-0.129 * * *$ & -0.001 \\
\hline $25-34$ & $0.066^{* * *}$ & $-0.059 * * *$ & -0.007 \\
\hline $35-44$ & Ref. & Ref. & Ref. \\
\hline $45-54$ & 0.011 & 0.005 & $-0.016^{* *}$ \\
\hline $55-64$ & $0.033^{* *}$ & -0.004 & $-0.029 * * *$ \\
\hline $65+$ & $0.164 * * *$ & $-0.130 * * *$ & $-0.034 * *$ \\
\hline \multicolumn{4}{|l|}{ Education } \\
\hline Primary & $0.046 * * *$ & $-0.053 * * *$ & 0.007 \\
\hline Secondary & Ref. & Ref. & Ref. \\
\hline Vocational & $-0.052 * * *$ & $0.054 * * *$ & -0.002 \\
\hline Tertiary & $-0.065^{* * *}$ & $0.092 * * *$ & $-0.027 * * *$ \\
\hline Student & $0.286 * * *$ & $-0.250 * * *$ & $-0.036 * * *$ \\
\hline Retired & $0.519 * * *$ & $-0.477 * * *$ & $-0.042 * * *$ \\
\hline Assisting in family business & $0.089 * * *$ & $-0.153 * * *$ & $0.064 * * *$ \\
\hline Linguistic minority & $-0.014 * *$ & -0.005 & $0.019 * * *$ \\
\hline Income/10 & $-0.005 * * *$ & $0.004 * * *$ & $0.001 * * *$ \\
\hline Poor health & $0.027 * * *$ & $-0.030 * * *$ & 0.004 \\
\hline \multicolumn{4}{|l|}{ Type of settlement } \\
\hline Village & $0.015^{*}$ & $-0.030 * * *$ & $0.014 * *$ \\
\hline Small town & Ref. & Ref. & Ref. \\
\hline Regional centre & 0.017 & $-0.018^{*}$ & 0.001 \\
\hline Capital & -0.008 & 0.003 & 0.005 \\
\hline \multicolumn{4}{|l|}{ Country } \\
\hline Ukraine & Ref. & Ref. & Ref. \\
\hline Tajikistan & $0.151 * * *$ & $-0.170 * * *$ & $0.019^{* *}$ \\
\hline Serbia & $0.152 * * *$ & $-0.071 * * *$ & $-0.081 * * *$ \\
\hline Macedonia & $0.210 * * *$ & $-0.148 * * *$ & $-0.062 * * *$ \\
\hline Moldova & $0.057 * * *$ & $-0.035 * * *$ & $-0.022 * *$ \\
\hline Kazakhstan & $0.081 * * *$ & $-0.084 * * *$ & 0.003 \\
\hline Observations & & 14,310 & \\
\hline Wald $\mathrm{Chi}^{2}$ & & 3029 & \\
\hline Prob $>\mathrm{Chi}^{2}$ & & 0.000 & \\
\hline
\end{tabular}

Note: ${ }^{* * *} \mathrm{p}<0.01, * * \mathrm{p}<0.05,{ }^{*} \mathrm{p}<0.1$. Robust standard errors used to calculate the regressors' level of significance. Average marginal effects. 
Table 2. Receiving remittances and labour market outcomes by country, multinomial probit marginal effects

\begin{tabular}{lccc}
\hline & Not working & Formal work & Informal work \\
\hline & & & \\
FYR of Macedonia & 0.033 & -0.021 & -0.012 \\
Moldova & $0.070^{* * *}$ & $-0.074^{* * *}$ & 0.004 \\
Kazakhstan & -0.000 & -0.019 & 0.020 \\
Serbia & 0.009 & -0.021 & 0.013 \\
Tajikistan & 0.010 & $-0.037^{* *}$ & $0.027 * *$ \\
Ukraine & $0.098^{* *}$ & $-0.104^{*}$ & 0.006 \\
\hline
\end{tabular}

Note: $* * * \mathrm{p}<0.01, * * \mathrm{p}<0.05, * \mathrm{p}<0.1$. Robust standard errors used to calculate the regressors' level of significance. Each line reports the average marginal effects of the remittances variable from a model estimated for a particular country. The same socio-demographic controls as in Table 1 are included in all regressions; their marginal effects are not reported to save space. Sample size for the six estimations ranges from 2,187 to 2,533. In all regressions, the Wald test rejects $(\mathrm{p}=0.000)$ the hypothesis that all regressors are equal to 0 . Complete econometric output is available on request.

The results reported in Tables 1 and 2 are best described as conditional correlations. There is no guarantee that they represent the effect of receiving remittances on different labour market outcomes. As argued earlier, households may send migrants abroad with an expectation of receiving remittances and either exiting the labour force or moving into the informal sector at a later stage. The decision to migrate and send remittances back home can, thus, be a consequence, and not a cause, of the decision of some household members to change their labour market status. In addition, unobserved household characteristics may push some members of a household into unemployment/ informality at home and others into migration.

To correct for the potential endogeneity of remittances, I perform instrumental variable (2SRI) analysis. The results of the first stage regression are reported in the first column of Table 3. All three instruments are highly significant. As expected, within-settlement ethnic minority respondents and households which were engaged in subsistence agriculture in 1985 are more likely to receive remittances; furthermore, respondents living in ethnically mixed settlements are also more likely to receive remittances. The instruments jointly satisfy the relevance condition, with the value of the F test of excluded instruments equal to 28.01. The validity of the instruments is further confirmed by the overidentification test which rejects the hypothesis that instruments are endogenous $(\mathrm{p}=0.145)$.

Columns 2-4 of table 2 show the results of the 2SRI second stage equation, which includes the first stage predicted residuals alongside the endogenous regressor and control variables. The statistically significant coefficient of the predicted residuals for the unemployed and 
informal-work outcomes indicates that the endogeneity is present in the model and the 2SRI results should be used. The instrumental variable results suggest receiving remittances reduces the likelihood the of being out of labour force by 30 percentage points, does not have a significant effect on the likelihood of being employed formally and increases the probability of informal employment by 18 percentage points. It thus appears that remittances encourage people to move from labour market inactivity into informal employment. 
Table 3. Receiving remittances and labour market outcomes: 2SRI multinomial probit first stage results and second stage marginal effects

\begin{tabular}{|c|c|c|c|c|}
\hline & \multirow[b]{2}{*}{$1^{\text {st }}$ stage } & \multicolumn{3}{|c|}{$2^{\text {nd }}$ stage $2 \mathrm{SRI}$ average marginal effects } \\
\hline & & $\begin{array}{c}\text { Not } \\
\text { working }\end{array}$ & $\begin{array}{c}\text { Formal } \\
\text { work }\end{array}$ & $\begin{array}{c}\text { Informal } \\
\text { work }\end{array}$ \\
\hline Receives remittances & Dep.var. & $-0.303^{* *}$ & 0.123 & 0.180* \\
\hline $1^{\text {st }}$ stage predicted residuals & - & $0.348 * * *$ & -0.183 & $-0.165 *$ \\
\hline Female & $0.027 * * *$ & $0.087 * * *$ & $-0.030 * * *$ & $-0.056^{* * *}$ \\
\hline Has child(ren) & $0.021 * * *$ & -0.003 & -0.001 & 0.005 \\
\hline \multicolumn{5}{|l|}{ Age } \\
\hline $18-24$ & $0.027 * *$ & $0.139 * * *$ & $-0.134 * * *$ & -0.005 \\
\hline $25-34$ & $0.017 * *$ & $0.072 * * *$ & $-0.062 * * *$ & -0.010 \\
\hline $35-44$ & Ref. & Ref. & Ref. & Ref. \\
\hline $45-54$ & $0.025 * * *$ & $0.020 * *$ & -0.000 & $-0.020 * * *$ \\
\hline $55-64$ & $0.031 * * *$ & $0.044 * * *$ & -0.009 & $-0.034 * * *$ \\
\hline $65+$ & 0.015 & $0.170 * * *$ & $-0.133 * * *$ & $-0.037 * *$ \\
\hline \multicolumn{5}{|l|}{ Education } \\
\hline Primary & $-0.021 * * *$ & $0.039 * * *$ & $-0.049 * * *$ & 0.010 \\
\hline Secondary & Ref. & Ref. & Ref. & Ref. \\
\hline Vocational & $-0.021 * * *$ & $-0.059 * * *$ & $0.057 * * *$ & 0.002 \\
\hline Tertiary & $-0.028 * * *$ & $-0.075 * * *$ & $0.097 * * *$ & $-0.022 * * *$ \\
\hline Student & 0.023 & $0.293 * * *$ & $-0.254 * * *$ & $-0.039 * * *$ \\
\hline Retired & -0.002 & $0.518 * * *$ & $-0.476^{* * *}$ & $-0.041 * * *$ \\
\hline Assisting in family business & -0.017 & $0.083 * * *$ & $-0.150 * * *$ & $0.067 * * *$ \\
\hline Linguistic minority & -0.008 & $-0.012 *$ & -0.007 & $0.018 * * *$ \\
\hline Income/10 & 0.000 & $-0.005 * * *$ & $0.004 * * *$ & $0.001 * * *$ \\
\hline Poor health & $-0.011 * * *$ & $0.023 * * *$ & $-0.028 * * *$ & $0.005 * *$ \\
\hline \multicolumn{5}{|l|}{ Type of settlement } \\
\hline Village & $0.029 * * *$ & $0.026 * * *$ & $-0.035^{* * *}$ & 0.009 \\
\hline Small town & Ref. & Ref. & Ref. & Ref. \\
\hline Regional centre & $0.021 * * *$ & $0.023 * *$ & $-0.021 * *$ & -0.002 \\
\hline Capital & $-0.034 * * *$ & $-0.022 *$ & 0.011 & 0.012 \\
\hline \multicolumn{5}{|l|}{ Country } \\
\hline Ukraine & Ref. & Ref. & Ref. & Ref. \\
\hline Tajikistan & $0.250 * * *$ & $0.239 * * *$ & $-0.216^{* * *}$ & -0.023 \\
\hline Serbia & $0.016^{* *}$ & $0.157 * * *$ & $-0.073 * * *$ & $-0.083 * * *$ \\
\hline Macedonia & $0.052 * * *$ & $0.225 * * *$ & $-0.156 * * *$ & $-0.070 * * *$ \\
\hline Moldova & $0.224 * * *$ & $0.134 * * *$ & $-0.075 * *$ & $-0.059 * * *$ \\
\hline Kazakhstan & $-0.028 * * *$ & $0.076^{* * *}$ & $-0.081 * * *$ & 0.006 \\
\hline \multicolumn{5}{|l|}{ Instruments } \\
\hline Within-settlement minority & $0.050 * * *$ & & & \\
\hline Ethnically mixed settlement & $0.037 * * *$ & & & \\
\hline Subsistence agriculture in 1985 & $0.034 * * *$ & & & \\
\hline F test of excluded instruments & $28.01 * * *$ & & & \\
\hline Overidentification test & 0.145 & & & \\
\hline Observations & & 14,310 & & \\
\hline Wald Chi ${ }^{2}$ & & 3031 & & \\
\hline Prob $>\mathrm{Chi}^{2}$ & & 0.000 & & \\
\hline
\end{tabular}




\subsection{Remittances and labour market outcomes of non-migrant households}

Do remittances encourage informal employment among the non-migrant households? One way to shed light on this question is to relate the regional variation in the share of remittancereceivers to labour market outcomes of people who do not receive remittances. Table 4 reports conditional correlations between the region-level share of households receiving remittances (the share of remittance receivers in a region is on average $12.7 \%$, ranging from $0 \%$ to $91.7 \%)^{9}$ and the probability of not working, working formally and working informally for people who do not receive remittances (remittances receivers are excluded from analysis).

The results for the six-country sample, and the corresponding predicted probabilities (Figure 1), suggest that, among people who do not receive remittances, higher region-level remittance intensity is associated with a higher likelihood of working informally and a lower likelihood of working formally; the likelihood of 'not working' is not significantly correlated with the regional share of remittance receivers. In terms of magnitudes, an increase in the district-level share of remittance receivers by 10 percentage points is associated with a 1.35 percentage points higher probability of working informally $(3.65 \%$ increase relative to the average incidence of informal work) and an approximately 1.61 percentage points lower probability of working formally ( $2.94 \%$ decrease relative to the average incidence of formal work).

Table 5 reports the results of the model estimated for each of the six countries. The marginal effect for the informal work outcome is positive in all six countries and statistically significant in three: Macedonia, Serbia and Tajikistan. The marginal effects for the formal work outcome tend to be negative, but are statistically significant only in Serbia.

It should be noted that correlational results shown in Tables 4 and 5 do not necessarily represent the effect of remittances on the labour market outcomes of non-migrant households. Reverse causality is possible as people may wish to emigrate (and send remittances back home) if informal employment is widespread in their region. Another source of endogeneity is omitted variables affecting both the local-level emigration and informal employment. Dealing with the potential endogeneity and establishing causal effects of remittances on the

\footnotetext{
${ }^{9}$ The total number of regions/districts in six countries is 208 (on average 35 per country). The share is calculated by dividing the number of remittances receiving households by the total number of households in a region.
} 
informal employment of non-migrant households is beyond the scope of this study and represents an important direction for future research.

Table 4. Region-level share of remittance receivers and labour market outcomes of people not receiving remittances. Multinomial probit average marginal effects

\begin{tabular}{|c|c|c|c|}
\hline & $\begin{array}{c}\text { Not } \\
\text { working }\end{array}$ & $\begin{array}{c}\text { Formal } \\
\text { work }\end{array}$ & $\begin{array}{c}\text { Informal } \\
\text { work }\end{array}$ \\
\hline Share of remittance receivers in a region ( 0 to 1$)$ & 0.026 & $-0.161 * * *$ & $0.135 * * *$ \\
\hline Female & $0.068 * * *$ & $-0.024 * * *$ & $-0.044 * * *$ \\
\hline Has child(ren) & -0.005 & 0.003 & 0.003 \\
\hline \multicolumn{4}{|l|}{ Age } \\
\hline $18-24$ & $0.126^{* * *}$ & $-0.136 * * *$ & 0.010 \\
\hline $25-34$ & $0.070 * * *$ & $-0.066 * * *$ & -0.005 \\
\hline $35-44$ & Ref. & Ref. & Ref. \\
\hline $45-54$ & 0.015 & 0.003 & $-0.018 * * *$ \\
\hline $55-64$ & $0.039 * *$ & -0.009 & $-0.030 * * *$ \\
\hline $65+$ & $0.164 * * *$ & $-0.133 * * *$ & $-0.031 *$ \\
\hline \multicolumn{4}{|l|}{ Education } \\
\hline Primary & $0.044 * * *$ & $-0.057 * * *$ & 0.013 \\
\hline Secondary & Ref. & Ref. & Ref. \\
\hline Vocational & $-0.054 * * *$ & $0.054 * * *$ & -0.000 \\
\hline Tertiary & $-0.059 * * *$ & $0.082 * * *$ & $-0.023 * * *$ \\
\hline Student & $0.288 * * *$ & $-0.263 * * *$ & $-0.025 *$ \\
\hline Retired & $0.506^{* * *}$ & $-0.482 * * *$ & -0.024 \\
\hline Assisting in family business & $0.068 *$ & $-0.147 * * *$ & $0.079 * * *$ \\
\hline Linguistic minority & -0.012 & -0.007 & $0.020 * * *$ \\
\hline Income/10 & $-0.004 * * *$ & $0.004 * * *$ & $0.000 * * *$ \\
\hline Poor health & $0.030 * * *$ & $-0.035 * * *$ & $0.005^{*}$ \\
\hline \multicolumn{4}{|l|}{ Type of settlement } \\
\hline Village & $0.027 * *$ & $-0.040 * * *$ & $0.013 *$ \\
\hline Small town & Ref. & Ref. & Ref. \\
\hline Regional centre & 0.018 & -0.021 & 0.003 \\
\hline Capital & -0.011 & -0.005 & 0.015 \\
\hline \multicolumn{4}{|l|}{ Country } \\
\hline Ukraine & Ref. & Ref. & Ref. \\
\hline Tajikistan & $0.163 * * *$ & $-0.142 * * *$ & -0.021 \\
\hline Serbia & $0.158 * * *$ & $-0.077 * * *$ & $-0.081 * * *$ \\
\hline Macedonia & $0.211 * * *$ & $-0.147 * * *$ & $-0.065 * * *$ \\
\hline Moldova & $0.055 * * *$ & 0.005 & $-0.060 * * *$ \\
\hline Kazakhstan & $0.088 * * *$ & $-0.087 * * *$ & -0.001 \\
\hline Observations & 12,494 & 12,494 & 12,494 \\
\hline Wald $\mathrm{Chi}^{2}$ & 2949.51 & & \\
\hline Prob $>\mathrm{Chi}^{2}$ & 0.000 & & \\
\hline
\end{tabular}

Note: $* * * p<0.01,{ }^{* *} \mathrm{p}<0.05, * \mathrm{p}<0.1$. Robust standard errors, clustered at the region level, used to calculate the regressors' level of significance. Average marginal effects. The regression excludes people who do not receive remittances. The regional share of remittances receivers varies from $0(0 \%)$ to $0.92(92 \%)$. 
Figure 1. Predicted probabilities of working informally, working formally and not working among people who do not receive remittances, as a function of the regional share of remittance receivers

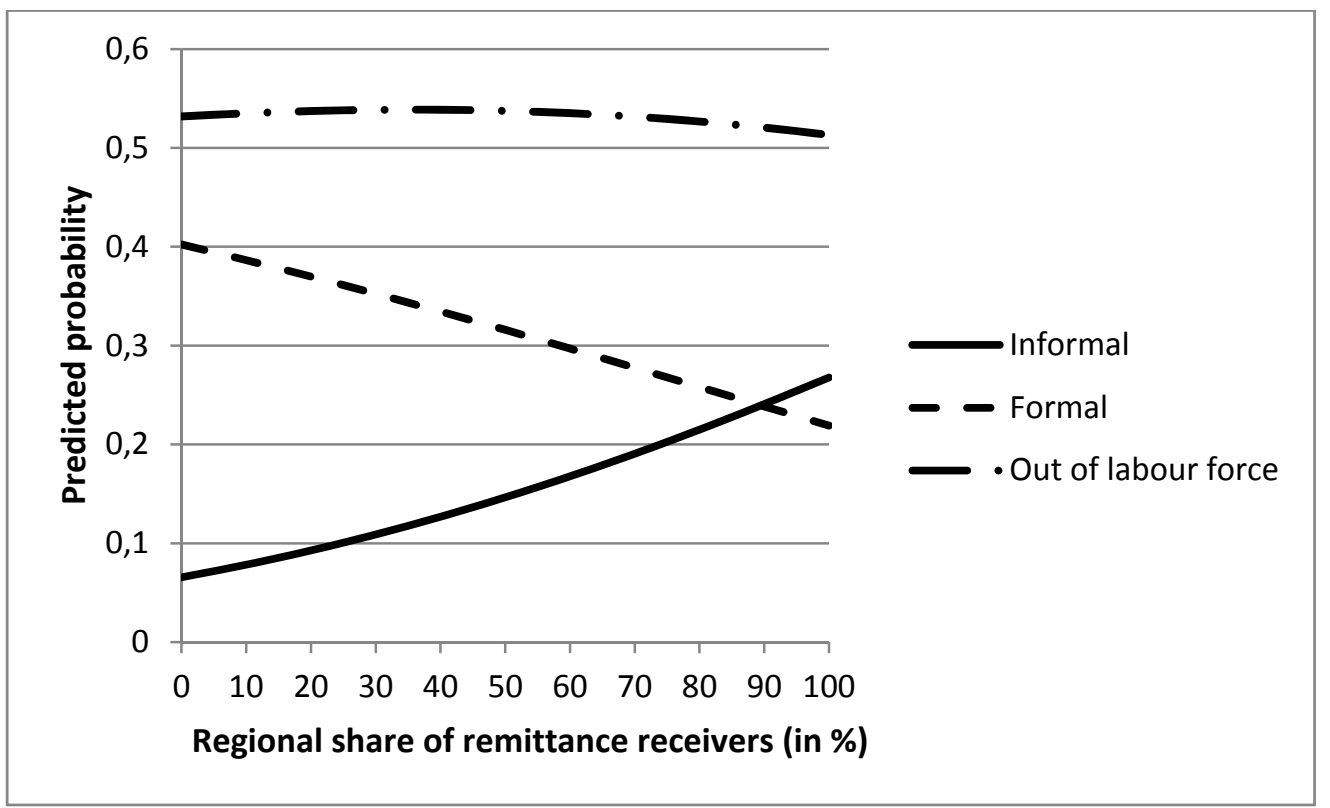

Table 5. Region-level share of remittance receivers and labour market outcomes of people not receiving remittances, by country. Multinomial probit average marginal effects

\begin{tabular}{lccc}
\hline & Not working & Formal work & Informal work \\
\hline & & & \\
FYR of Macedonia & -0.182 & -0.007 & $0.189^{* *}$ \\
Moldova & 0.093 & -0.132 & 0.039 \\
Kazakhstan & 0.559 & -0.592 & 0.033 \\
Serbia & 0.234 & $-0.467^{* *}$ & $0.233^{* * *}$ \\
Tajikistan & -0.116 & -0.034 & $0.150^{* *}$ \\
Ukraine & -0.127 & 0.008 & 0.119 \\
\hline
\end{tabular}

Note: $* * * \mathrm{p}<0.01, * * \mathrm{p}<0.05, * \mathrm{p}<0.1$. Robust standard errors, clustered at the region level, used to calculate the regressors' level of significance.Each line reports the average marginal effects of the regional share of remittance receivers variable from a model estimated for a particular country. The same socio-demographic controls as in Table 4 are included in all regressions; their marginal effects are not reported to space. Sample size for the six estimations ranges from 1,734 to 2,474 (regressions excluded people who receive remittances). Complete econometric output is available on request.

\section{DISCUSSION AND CONCLUSION}

This paper has studied the effects of receiving migrant remittances on the likelihood of informal work among the members of the remittance-recipient households, as well as the local-level effects of remittances on the likelihood of informal work among the non-migrant households. Using a large survey from six transition economies, I found that people receiving remittances are more likely to work informally than people with similar characteristics but 
not receiving remittances. The instrumental variable analysis confirmed that remittances have a positive effect on informal employment. Two explanations for this finding are: 1) remittances provide the household with a capital to start a new business or become selfemployed - a type of employment which is often informal - and 2) remittances represent a safety net encouraging remittance-receivers to choose less secure, but often more lucrative, informal work.

I also obtained a positive and significant district-level association between the share of remittance-receivers and the likelihood of working informally among people who do not receive remittances. One possible explanation is the 'new businesses' effect: remittances encourage the formation of small enterprises which informally employ local people who do not receive remittances. Another explanation is the 'neighbours' effect: the non-migrant households want to keep up with the consumption levels of the remittance-receiving neighbours and, to raise the money, may decide either work more or to send a migrant abroad. Working informally is a quick way to raise money directly or to cover migration costs.

The analysis conducted at the county level reveals that, among the six transition economies, Tajikistan is the only country where remittances encouraged informal employment of both migrant and non-migrant households. It is important to compare this finding with Abdulloev et al. (2012) - the only other study exploring the links between migration and informality, and doing so using data from Tajikistan. Abdulloev et al. (2012) argue that migration and informal activities are substitutes: the low-skilled people in Tajikistan choose to migrate while the high-skilled people choose to work in the lucrative (upper-tier) segment of the local informal economy. The authors support this conjecture by the empirical finding that remittance-receiving households have a lower gap between reported expenditures and reported income (a proxy for being involved in informal activities) than the non-migrant households. At first view, the results of Abdulloev at al. (2012) may seem in conflict with the results of our study. However, a closer inspection of the definitions of informality may help reconcile the results of the two papers. As in many other parts of the post-socialist world, Tajik people working in the lucrative segment of the local informal economy are likely to be paid a minimum declared wage, for which they will have a formal work contract; the remainder of the wage, probably its biggest part, is likely to be paid in the 'envelope', i.e. undeclared to the state (see e.g. Williams (2009)). In Abdulloev et al. (2012) the receivers of 'envelope' wages would be considered informal workers, as their reported expenditures 
exceed reported income, but in our analysis they are likely to be formal (i.e., they would answer 'yes' to the question, "Do you have a formal contract in your main job?"). In contrast, people who do not have a formal contract in their main job ('informal work' in this paper) are likely to be employed in the lower-tier informal sector (small firms, family businesses, self-employed), receive a relatively low wage and, possibly, have a lower gap between reported expenditures and income (i.e. less likely to be involved in informal activities according to the definition of informality adopted by Abdulloev at al. (2012)). So, whether remittances and informality are substitutes or complements may depend on whether one considers the upper or the lower tier of the informal market. In this paper, I have used the 'formal work contract' definition of informality and most likely captured the lower tier of the informal market. The analysis of richer data, allowing to distinguish the receivers of 'envelope' wages from people whose entire wage is undeclared, would provide a more nuanced picture of the effects of remittances on informal employment and represents another direction for future research.

Overall, the results of this paper suggest that remittances are either associated with or lead to more informality in the sending countries. This finding makes remittances a controversial policy instrument: while informal work represents an efficient way to deal with poverty in the short term, extensive informal sector results in low fiscal capacity of the state and low trust in state institutions, which undermines development in the long term. 


\section{References}

Abdulloev, I. Gang, I.N., Landon-Lane, J. (2012) Migration as a Substitute for Informal Activities: Evidence from Tajikistan. Research in Labor Economics Vol. 34: 205 - 227.

Acosta, P (2007) Entrepreneurship, Labour Markets, and International Remittances: Evidences from El Salvador. In Ozden, C. and Schiff, M. (Eds), International Migration, Economic Development and Policy. (pp. 141-159).Washington DC: World Bank Publication.

Airola, J. (2008) Labor Supply in Response to Remittance Income: The Case of Mexico. Journal of Developing Areas 41(2): 69-78.

Alesina, A., Devleeschauwer, A., Easterly, W., Kurlat, S., Wacziarg, R. (2003) Fractionalization. Journal of Economic Growth 8: 155-194.

Alesina, A., La Ferrara, E. (2005) Ethnic Diversity and Economic Performance. Journal of Economic Literature 43 (3): 762-800.

Amuedo-Dorantes, C., Pozo, S. (2006) Migration, Remittances, and Male and Female Employment Patterns. American Economic Review 96(2): 222-226.

Binzel, C., Assaad, R. (201) Egyptian men working abroad: Labour supply responses by the women left behind. Labour Economics 18(S1): S98-S114.

Bollen K.A., Guilkey, D.K. and Mroz, T.A. (1995) Binary outcomes and endogenous explanatory variables: tests and solutions with an application to the demand for contraceptive use in Tunisia. Demography, 32: 111-131.

Buehn, A., Schneider, F. (2012) Shadow economies around the world: novel insights, accepted knowledge and new estimates. International Tax and Public Finance 19(1): $139-171$.

Clifton, J. (2013) More Than 100 Million Worldwide Dream of a Life in the U.S. Gallup World. Available at http://www.gallup.com/poll/161435/100-million-worldwidedream-life.aspx

Docquier, F. and Rapoport, H. (2003) Ethnic discrimination and the migration of skilled labor. Journal of Development Economics 70(1): 159-172.

Drinkwater, S., Levine, P., Lotti, E. (2009) Labor Market and Investment Effects of Remittances. In Development Macroeconomics: Essays in Memory of Anita Ghatak, edited by Subrata Ghatak and Paul Levine, 229-51, Abingdon, Oxon: Routledge.

Fearon, J. and Laitin, D. (2003) Ethnicity, Insurgency, and Civil War. American Political Science Review 97(1): 75-90.

Gagnon, J. and Khoudour-Castéras, D. (2011) Tackling the Policy Challenges of Migration. Regulation, integration, development, Paris, OECD Development Centre. 
Gisselquist, R., S. Leiderer and M. Niño-Zarazúa (2016), Ethnic Heterogeneity and Public Goods Provision in Zambia: Evidence of a Subnational "Diversity Dividend", World Development 78: 308-323.

Hanson, G. (2007) Emigration, Remittances, and Labor Force Participation in Mexico. Integration and Trade Journal 11(27): 73-103.

Hughes, J. (2005) "Exit" in deeply divided societies: regimes of discrimination in Estonia and Latvia and the potential for Russophone migration. Journal of Common Market Studies: 43(4): 739-762.

Jackman, M. (2014) A note on the labor market effects of remittances in Latin American and Caribbean countries: do thresholds exist? The Developing Economies 1: 52-67.

Jadotte, E. (2009) International Migration, Remittances and Labor Supply: The Case of the Republic of Haiti. UNU-WIDER Research Paper no. 2009/28. Helsinki:World Institute for Development Economics Research.

Justino, P., Shemyakina, O.N. (2012) Remittances and Labour Supply in Post-Conflict Tajikistan. IZA Journal of Labour and Development 1:8.

Ivlevs, A. (2013) Minorities on the move? Assessing post-enlargement emigration intentions of Latvia's Russian speaking minority. Annals of Regional Science 51(1): 33-52.

Ivlevs, A., and King, R. (2012) Does more schooling make you run for the border? Postindependence evidence from Kosovo. Journal of Development Studies 48(8): 1108-1120.

Lehmann, H., and Myravyev, A. (2014) Labor Market Institutions and Informality in Transition and Latin American Countries. In Froelich, M., Kaplan, D., Pages, C., Rigolini, J. and D. Robalino (Eds.): Social Insurance and Labor Markets: How to Protect Workers while Creating Good Jobs, Oxford University Press.

Lewis, W. A. (1954) Economic Development with Unlimited Supplies of Labor. Manchester School of Economic and Social Studies 22: 139-91.

Kim, N. (2007) The Impact of Remittances on Labor Supply: The Case of Jamaica. World Bank Policy Research Working Paper no. 4120. Washington, DC: World Bank.

Koettl, J., and Weber, M. (2012), "Does Formal Work Pay? The Role of Labor Taxation and Social Benefit Design in the New EU Member States", Research in Labor Economics 34: 167-204.

Miguel, E. and Gugerty, M.K. (2005) Ethnic diversity, social sanctions, and public goods in Kenya. Journal of Public Economics 89(11): 2325-2368.

Montalvo, J., Reynal-Querol, M. (2005) Ethnic Polarization, Potential Conflict and Civil Wars. American Economic Review 95: 796-81.

OECD (2009) Is Informal Normal? Towards More and Better Jobs in Developing Countries. OECD Publishing, Paris. 
Pichler, R. (2009) Migration, Architecture and the Imagination of Home(land). An AlbanianMacedonian Case Study. In Brunnbauer, U. (ed.): Transnational Societies,

Transterritorial Politics. Migrations in the (Post-) Yugoslav Region, 19th-21st Century. Munich: R. Oldenbourg Verlag.

Piracha, M., Randazzo, T., Vadean, F. (2013) Remittances and Occupational Outcomes of the Household Members Left-Behind. IZA Discussion Paper No.7582

Posso, A. (2012) Remittances and Aggregate Labour Supply: Evidence from 66 Developing Nations. The Developing Economies 50 (1), 25-39.

Stark, O. (1991) The migration of labor. Cambridge, Massachusetts: Blackwell Publishers.

Stark, O. (2009) Reasons for Remitting. World Economics 10(3): 147-157.

Stark, O. and Bloom, E. D. (1985). The New Economics of Labor Migration. American Economic Review 75(2): 173-178.

Staneva, A. and Arabsheibani, R. (2014) Is there informal employment wage premium? Evidence from Tajikistan. IZA Journal of Labour and Development 3: 1.

Terza, J.V., Basu, A. and Rathouz, P.J. (2008) Two-stage residual inclusion estimation: Addressing endogeneity in health econometric modeling. Journal of Health Economics, 27(3): 531-543.

United Nations, Department of Economic and Social and Social Affairs (UN-DESA) \& OECD (2013) World Migration in Figures. http://www.oecd.org/els/mig/WorldMigration-in-Figures.pdf

United Nations Development Programme, Beyond Transition: Towards Inclusive Societies. UNDP Regional Human Development Report, Bratislava, 2011.

Williams, C.C. (2009) The commonality of envelope wages in Eastern European economies. Eastern European Economics, 47 (2): 37-52.

Williams, C. C. (2015) Cross-national variations in the scale of informal employment. International Journal of Manpower, 36(2): 118-135.

World Bank (2014) Migration and Remittances: Recent Developments and Outlook* Special Topic: Forced Migration. Migration and Development Brief 23. World Bank, Washington, D.C. 
Appendix.

Summary statistics

\begin{tabular}{|c|c|c|c|c|}
\hline & Mean & $\begin{array}{l}\text { Standard } \\
\text { deviation }\end{array}$ & Min & Max \\
\hline \multicolumn{5}{|l|}{ Labour market status } \\
\hline Working formally & 0.548 & 0.498 & 0 & 1 \\
\hline Working informally & 0.370 & 0.483 & 0 & 1 \\
\hline Not working & 0.082 & 0.274 & 0 & 1 \\
\hline Households receives remittances & 0.127 & 0.333 & 0 & 1 \\
\hline Share of remittance receivers in a region & 0.127 & 0.160 & 0 & 0.917 \\
\hline Female & 0.545 & 0.498 & 0 & 1 \\
\hline Has child(ren) & 0.462 & 0.499 & 0 & 1 \\
\hline \multicolumn{5}{|l|}{ Age } \\
\hline $18-24$ & 0.179 & 0.383 & 0 & 1 \\
\hline $25-34$ & 0.194 & 0.396 & 0 & 1 \\
\hline $35-44$ & 0.186 & 0.389 & 0 & 1 \\
\hline $45-54$ & 0.171 & 0.377 & 0 & 1 \\
\hline $55-64$ & 0.132 & 0.338 & 0 & 1 \\
\hline $65+$ & 0.139 & 0.346 & 0 & 1 \\
\hline \multicolumn{5}{|l|}{ Education } \\
\hline Primary & 0.238 & 0.426 & 0 & 1 \\
\hline Secondary & 0.408 & 0.491 & 0 & 1 \\
\hline Vocational & 0.169 & 0.375 & 0 & 1 \\
\hline Tertiary & 0.185 & 0.389 & 0 & 1 \\
\hline Student & 0.080 & 0.271 & 0 & 1 \\
\hline Retired & 0.203 & 0.402 & 0 & 1 \\
\hline Assisting in family business & 0.017 & 0.128 & 0 & 1 \\
\hline Linguistic minority & 0.309 & 0.462 & 0 & 1 \\
\hline Equivalised household income (PPP USD) & 302.60 & 365.91 & 0 & 5032.63 \\
\hline Poor health (high = less healthy) & 3.155 & 1.118 & 1 & 5 \\
\hline \multicolumn{5}{|l|}{ Type of settlement } \\
\hline Village & 0.488 & 0.500 & 0 & 1 \\
\hline Small town & 0.188 & 0.391 & 0 & 1 \\
\hline Regional centre & 0.197 & 0.398 & 0 & 1 \\
\hline Capital & 0.126 & 0.332 & 0 & 1 \\
\hline Within-settlement minority & 0.167 & 0.373 & 0 & 1 \\
\hline Ethnically-mixed settlement & 0.144 & 0.351 & 0 & 1 \\
\hline Subsistence agriculture in 1985 & 0.340 & 0.474 & 0 & 1 \\
\hline
\end{tabular}

